\title{
Numerical Study of Heat and Mass Transfer during the Thermal Drying of Tropical Woods
}

\author{
Merlin Simo Tagne* \\ Douala Higher Institute of Technology, Douala, Cameroon, PO Box 1623
}

\begin{abstract}
A sector of utilization and transformation of wood give much money at the countries of the central Africa region. If we want to increase these advantages, it is important to do locally the first and second transformations of wood. Self-control of the wood drying is necessary to ameliorate a wood quality and to preserve an art work doing in wood. In this article, we are modeling a drying of one piece of bete wood (Mansonia altissima) with dimensions are $1 \mathrm{~m}$ of length and thickness is no more than $25 \mathrm{~cm}$. We have used a literature to obtain a mass and heat equations and the thermophysical properties of the present wood. We have considered some thermophysical properties that we are unkempt in the precedent work [1]. We have experimentally obtained a relationship between a density of this wood with a water content. The others thermophysical properties come from the literature [1,2]. We have simulated a wood drying in the constant conditions and in the conditions of the bete drying table established by CIRAD Organization. A sensibility study is doing to validate a modeling. Then, the present modeling explains temperature, mass fraction of the vapor in air and water content evolutions during the industrial process of drying. This modeling can to be used for to overhaul a drying table of bete wood and the others of tropical woods. This work uses a gaseous pressure can be used to explain the drying with the high temperatures conditions.
\end{abstract}

Keywords: Drying-Heat and Mass Transfer-Forced Convection-Modeling-Finite Difference-Mansonia Altissima

\section{Introduction}

Tropical countries have vast forests that contain many species of wood [3-5]. These varieties enable the majority of the principal European and Asian importing these woods to be very interested. Unfortunately, the majority of wood is exported from Africa in rough timber, as many African countries as Cameroon and Gabon require that the first transformation must be done locally [6]. In effect, local transformation of wood enables job creation, promotes employment relative to the transformation of the wood and to struggle against deterioration of the exchange terms because, when the wood is sold in Africa, there are to be comes very expensive. Though, economies of the tropical countries do independ of the exterior market and the effects as the recent worldly financial crisis. Cameroon has many forests and surface mine potentials to become one of the rich African countries [4]. Then it is very important to develop a technology and science of tropical countries in order to answer the immediate needs as preservation of wood by thermal drying. Thus, the utilization of the forest is optimized and ecological advantages as fixation of carbon, regeneration of oxygen, preservation of animal diversity, of grass and trees can be preserved. In this paper, we applied one model which explains the drying of tropical woods [1] to describe the drying the tropical woods applied on the bete (Mansonia altissima). This wood is abundant in the region of Central Africa and is highly demanded in the interior and exterior markets of Cameroon [7]. In the previous work [1], we are supposed that heat and mass transfer air are constant. In the present work, we take a real variation of all thermophysical parameters indicate in all equations of transfer with integration of air pressure. This supposition traduces a real behavior of industrial drying and can be used to ameliorate the drying tables of tropical woods and consequently, to ameliorate the quality of dried wood.

\section{Modeling and Thermophysical Parameters}

A present model is developed in the literature and has been validated with a numerical simulation of the drying of ayous and ebony woods in others conditions [1]. It is very difficult to use all drying models without simplifications because a drying process shows multidimensional characteristics and the

${ }^{*}$ Corresponding author. Tel.: +27394852402

E-mail: simotagne2002@yahoo.fr

(c) 2014 International Association for Sharing Knowledge and Sustainability

DOI: $10.5383 /$ ijtee.08.01.002 
samples to dry have many thermophysical parameters unknown [8]. Therefore, we are taking in this work the following hypothesis:

- A size of sample to dry is constant, homogeneous and it is chemically inert;

- As soon as the drying begins, water that comes from wood is made of vapor and free water, bound water is extracted when the fiber saturation point is obtained;

- We have a symmetric drying, therefore a median of the wood plank is an extreme temperature and water content;

- A heat transfer by convection takes place only at the level of thermal layer limit who to be at the borders of samples;

- We have neglected the transfer on the lateral faces. Transfers which take place are controlled by the thickness of the planks, which is smaller than width and length;

- Gravity effect and hydraulic conductivity of wood are neglected;

- $\quad$ The losses inherent in the dryer are not respected. All the other values are supposed to be transferred to the wood;

- $\quad$ Air and water are supposed to be incompressible.

We obtained the following equations (1) below [1]:

$\frac{\partial H}{\partial t}-\vec{\nabla} \cdot\left(\overline{\bar{D}}_{H H} \vec{\nabla} H+\overline{\bar{D}}_{H T} \vec{\nabla} T\right)=0$

$\rho_{s} C_{p} \frac{\partial T}{\partial t}-\vec{\nabla}\left(\overline{\bar{D}}_{T T} \vec{\nabla} T+\overline{\bar{D}}_{T H} \vec{\nabla} H\right)=\vec{\nabla}(\overline{\bar{\lambda}} \vec{\nabla} T)$

Between wood and air, we have:

$\overline{\bar{\lambda}} \vec{\nabla} T=\overline{\bar{h}}_{c}\left(T-T_{\text {air }}\right) \vec{n}+\rho_{l} L \overline{\bar{D}}_{H H} \vec{\nabla} H$

$-\overline{\bar{D}}_{H H} \vec{\nabla} H=\bar{h}_{m}\left(H-X_{e q}\right) \vec{n}$

with:

$\mathrm{H}$ : Water content of wood $(\mathrm{kg} / \mathrm{kg})$

T: Temperature of wood $(\mathrm{K})$

$\mathrm{t}$ : Drying time (s)

$h_{c}, h_{m}$ : Global coefficient transfer respectively of the heat $\left(\mathrm{W} /\left(\mathrm{m}^{2} \cdot \mathrm{K}\right)\right)$ and the mass $(\mathrm{m} / \mathrm{s})$

$\rho_{s}$ : Density of the anhydride wood $\left(\mathrm{kg} / \mathrm{m}^{3}\right)$

$\mathrm{X}_{\mathrm{eq}}$ : Equilibrium water content $(\mathrm{kg} / \mathrm{kg})$

$\mathrm{C}_{\mathrm{p}}$ : Specific heat capacity of wet wood $(\mathrm{J} /(\mathrm{kg} . \mathrm{K}))$

$\lambda$ : Thermal conductivity of wet wood $(\mathrm{W} /(\mathrm{m} . \mathrm{K}))$

At the median plane, the fluxes diffusion of humidity and heat are neglected.

Diffusions coefficients are such as:

$\overline{\bar{D}}_{H H}=\overline{\bar{D}}_{H}-\frac{\rho_{l} \bar{k}}{\rho_{s}}\left(\frac{\bar{k}_{r}}{\mu}\right)_{l} \frac{\partial P}{\partial H}+\frac{\rho_{g} \bar{D}_{g}}{\rho_{s}(1-C)} \frac{\partial C}{\partial H}$
$\overline{\bar{D}}_{H T}=\overline{\bar{D}}_{T}-\frac{\rho_{l} \overline{\bar{k}}}{\rho_{s}}\left(\frac{\bar{k}_{r}}{\mu}\right)_{l} \frac{\partial P_{c}}{\partial T}+\frac{\rho_{g} \overline{\bar{D}}_{g}}{\rho_{s}(1-C)} \frac{\partial C}{\partial T}$

Elements of second member of equations (2) and (3) indicate in the order the contributions of the coefficients to extract bound water, free water and the vapor of the water.

$$
\begin{aligned}
& \overline{\bar{D}}_{T T}=\frac{(E+L) \rho_{g} \overline{\bar{D}}_{g}}{1-C} \frac{\partial C}{\partial T}-E \rho_{l} \overline{\bar{k}}\left(\frac{\overline{\bar{k}}_{r}}{\mu}\right)_{l} \frac{\partial P_{c}}{\partial T} \\
& \overline{\bar{D}}_{T H}=\frac{(E+L) \rho_{g} \overline{\bar{D}}_{g}}{1-C} \frac{\partial C}{\partial H}-E \rho_{l} \overline{\bar{k}}\left(\frac{\overline{\bar{k}}_{r}}{\mu}\right)_{l} \frac{\partial P_{c}}{\partial H}
\end{aligned}
$$

Elements of second member of equations (2) and (3) indicate in the order the contributions of the energies to extract water in the state of vapor and in the state of liquid.

With : $D_{H}, D_{T}$ : diffusion coefficients of bound water respectively at a gradient humidity $\left(\mathrm{m}^{2} / \mathrm{s}\right)$ or at a gradient temperature $\left(\mathrm{m}^{2} /(\mathrm{Ks})\right)$;

E: heat desorption of the water absorbed $(\mathrm{J} / \mathrm{kg})$;

$\mathrm{L}$ : latent heat of the vaporization of liquid water $(\mathrm{J} / \mathrm{kg})$;

$\alpha$ : thermomigration coefficient $\left(\mathrm{K}^{-1}\right)$.

In the space order, terms of second member of the equations (4) and (5) show the energies contributions to extract water in vapor state or liquid state.

*Thermal conductivity of wood $(\mathrm{W} /(\mathrm{mK}))[2]$ :

$\lambda=\frac{\rho}{\rho_{l}}(0.2003+0.00548 H)+0.02378$

$\mathrm{H}$ in $\%$

*Specific heat capacity of wood (kJ/(kg.K)) [2] :

$C_{p}=\frac{C_{p o}+0.01 H C_{p w}}{1+0.01 H}+H\left(-0.06191+2.36 * 10^{-4} T-1.33 * 10^{-4} H\right)$

$\mathrm{H}$ in $\%$

$\mathrm{C}_{\mathrm{po}}=0.1031+0.003867 \mathrm{~T}$ and $\mathrm{C}_{\mathrm{pw}}=4.19 \mathrm{~kJ} /(\mathrm{kg} . \mathrm{K})$

$\mathrm{T}$ in Kelvin (K).Second term of second member of (7a) is equal to zero in a non hygroscopic domain, domain that is limit by the water content at the fiber saturation points (FSP).

*Fiber saturation points

We are experimental obtained this parameter after determination the water content of the wood where beginning the first variations of volume in each temperature. We have obtained the following equation :

$\mathrm{H}_{\mathrm{s}}=0.8397-0.0018 \mathrm{~T}_{\mathrm{a}} \quad$ avec $\mathrm{R}^{2}=0.9643$ et $\mathrm{T}_{\mathrm{a}}$ en $\mathrm{K}$

*Latent heat of vaporization $(\mathrm{J} / \mathrm{kg})[9]$ :

$\mathrm{L}=(3335-2.91 \mathrm{~T}) * 10^{3}$

$\mathrm{L}$ in $\mathrm{J} / \mathrm{kg}, \mathrm{H}$ in $\%$ and $\mathrm{T}$ in $\mathrm{K}$

*Desorption heat of the water adsorbed $(\mathrm{J} / \mathrm{kg})[10]$ :

$\mathrm{E}=1170.4 \times 10^{3} \exp (-0.14 \mathrm{H})$

$\mathrm{E}$ in $\mathrm{J} / \mathrm{kg}$ and $\mathrm{H}$ in \%.

*Coefficient of diffusion of the vapor of water in the air $\left(\mathrm{m}^{2} / \mathrm{s}\right)$ [11] : 
$D_{G}=2.25 \times 10^{-5} \frac{1}{P_{g}}\left(\frac{T_{a}}{273}\right)^{1,81}$

$\mathrm{P}_{\mathrm{g}}$ is the pressure of air estimated at $10^{5} \mathrm{~Pa}$.

* Coefficient of diffusion of the vapor of water in the wood $\left(\mathrm{m}^{2} / \mathrm{s}\right)[12]:$

$$
D_{g}=f D_{G}
$$

With $\mathrm{f}$ is brake factor which retain the diffusion of the vapor of water in the wood. We are taken the value $10^{-5}$ [12].

* Coefficient of diffusion of the bound water in the wood $\left(\mathrm{m}^{2} / \mathrm{s}\right)$ in the dimension $1[13]$ :

$D_{H}=\exp \left(-9.9+9.8 \cdot X_{e q}-\frac{4300}{T}\right)$

$\mathrm{T}$ in $\mathrm{K}$

*Coefficient of diffusion of the water in the wood caused to the gradient of temperature $\left(\mathrm{m}^{2} /(\mathrm{K} . \mathrm{s})\right)$ in the dimension 1 [14] :

$D_{T}=D_{H} \cdot \frac{d X_{e q}}{d T}$

*Wood permeability [15]:

$\mathrm{K}_{\mathrm{L}}=\mathrm{k} \cdot \mathrm{k}_{\mathrm{r}}=5 \times 10^{-18} \mathrm{~m}^{2}$

*Capillary pressure (Pa) [15]:

$P_{c}=\left(2.03 \times 10^{5} \varsigma \exp (-3.78 \varsigma)+93(1-\varsigma) \varsigma^{-1,4}\right)\left(1-2.19 \times 10^{-3}(T)\right)$

$\checkmark$ is the saturation of wood by the vapor and $\mathrm{T}$ in ${ }^{\circ} \mathrm{C}$.

$\varsigma=1-\frac{\rho_{h}}{1500}$

*Density of the water $\left(\mathrm{kg} / \mathrm{m}^{3}\right)$ [16]:

$\rho_{l}=-0.0038 T^{2}-0.0505 T+1002.6$

*Activation energy of the wood ( $/ \mathrm{mol})[17]$ :

$E_{b}=4.18\left(9200-7000 X_{e q}\right)$

*Density of the vapor of water $\left(\mathrm{kg} / \mathrm{m}^{3}\right)[16]$ :

$\rho_{g}=\frac{353}{T_{a}}$

$\mathrm{T}$ in $\mathrm{K}$

*mass fraction of the vapor [12]

$C=\frac{H R \cdot P_{v s a t}}{0.622\left(P_{g}-H R \cdot P_{v s a t}\right)}$

*Air humidity [12]:

$y=\frac{0.622 . H R \cdot P_{v s a t}}{P_{g}-H R \cdot P_{v s a t}}$

*Air humidity of the air at the saturation state (\%) [17]:

$Y_{\text {sat }}=\frac{10^{5}}{8.32\left(T_{a}+273\right)} \exp \left(14.02-\frac{5215}{T_{a}+273}\right)$

$\mathrm{T}_{\mathrm{a}}$ en ${ }^{\circ} \mathrm{C}$

*Pressure of the water in the saturation state (Pa) [18]:

$P_{v s a t}=\exp \left(25.5058-\frac{5204,9}{T_{a}}\right) \quad \mathrm{T}_{\mathrm{a}}$ in $\mathrm{K}$

*Soret effect coefficient $\left(\mathrm{K}^{-1}\right)$ [14]: $\alpha=\frac{d X_{e q}}{d T}=\frac{E_{b} H R}{R T^{2}} \frac{\partial X_{e q}}{\partial H R}$

*Energy of the activation of wood (J/mol) [19]:

$E_{b}=4.18\left(9200-7000 X_{e q}\right)$

*Equilibrium water content $(\mathrm{kg} / \mathrm{kg})$ [2]:

$X_{e q}=\frac{18}{w}\left[\frac{k_{o} H R}{1-k_{o} \cdot H R}+\frac{k_{1} k_{o} H R+2 k_{1} k_{2} k_{o}^{2} H R^{2}}{1+k_{1} k_{o} H R+k_{1} k_{2} k_{o}^{2} H R^{2}}\right]$

$w=349+1.29 T_{a}+0.0135 T_{a}^{2}$

$k_{o}=0.805+0.000736 T_{a}-0.00000273 T_{a}{ }^{2}$

$k_{1}=6.27-0.00938 T_{a}-0.000303 T_{a}^{2}$

$k_{2}=1.91+0.0407 T_{a}-0.000293 T_{a}^{2}$

$\mathrm{T}_{\mathrm{a}}$ in ${ }^{\circ} \mathrm{C}$

*Prandtl number [16]

Pr $=-2.54 * 10^{-4} \mathrm{~T}_{\mathrm{a}}+0.7147 \quad$ Ta en ${ }^{\circ} \mathrm{C}$

*Thermal conductivity of the air $(\mathrm{W} /(\mathrm{mK}))[16]$

$\lambda_{a}=7.57 \times 10^{-5} T_{a}+0.0242 \quad \mathrm{~T}_{\mathrm{a}}$ en ${ }^{\circ} \mathrm{C}$

*Dynamical viscosity of the air (Pa.s) [16]:

$\mu_{a}=10^{-5}\left(0.0046 T_{a}+1.7176\right) \quad \mathrm{T}_{\mathrm{a}}$ en ${ }^{\circ} \mathrm{C}$

* Dynamical viscosity of the water (Pa.s) [16]:

$\mu_{l}=10^{-4}\left(0.002 T_{a}{ }^{2}-0.3389 T_{a}+17.199\right) \quad \mathrm{T}_{\mathrm{a}}$ en ${ }^{\circ} \mathrm{C}$

*Mass transfer coefficient $(\mathrm{m} / \mathrm{s})[15]$ :

$h_{m}=9.454 \times 10^{-3} V_{a}^{0.5003}$

* Heat transfer coefficient $\left(\mathrm{W} /\left(\mathrm{m}^{2} . \mathrm{K}\right)\right)[15]$ :

$h_{c}=1.328 \frac{\lambda_{a}}{L_{p}} \operatorname{Re}^{1 / 2} \operatorname{Pr}^{1 / 3}$

*Density of wet wood:

We have experimentally determined this parameter. We have obtained:

$$
\rho_{s}=529.08 H+617.81 \quad \rho_{s} \text { in } \mathrm{kg} / \mathrm{m}^{3}
$$

With $\mathrm{H}$ in decimal and relative incertitude equal to $0.931 \%$.

*Expressions of all derivatives

Partial derivatives of the capillary pressure and the mass fraction of the vapor are being able to aggravate experimental noise. We have used the following equations:

$\frac{\partial C}{\partial T}=\frac{C\left(T_{\text {bois }}\right)-C\left(T_{\text {air }}\right)}{T_{\text {bois }}-T_{\text {air }}}$

$\frac{\partial C}{\partial H}=\frac{C\left(T_{\text {bois }}\right)-C\left(T_{\text {air }}\right)}{y\left(T_{\text {bois }}\right)-y\left(T_{\text {air }}\right)}$

$\frac{\partial P_{c}}{\partial T}=\frac{P_{c}\left(T_{b o i s}\right)-P_{c}\left(T_{a i r}\right)}{T_{\text {bois }}-T_{\text {air }}}$

$\frac{\partial P_{c}}{\partial H}=\frac{P_{c}\left(T_{\text {bois }}\right)-P_{c}\left(T_{\text {air }}\right)}{y\left(T_{\text {bois }}\right)-y\left(T_{\text {air }}\right)}$ 


\section{Numerical Method of the resolution}

To find numerical resolution of the analytical equations obtained, we have utilized the finite difference method. This method allows to approximate the values of continued functions and continually derivable by the development of Taylor's series. Implicit form is adapted at the resolution of differential equations less strongly coupled and to have the coefficients that less change. Coupling of these differential equations cannot envisage an analytical resolution. Wood plank is supposed to be a thick layer divided a $2 \mathrm{~N}+2$ series of thin layers, with in a half thickness the spaces orders $\mathrm{j}$ goes to 1 at $\mathrm{N}+1$. Forms of mass and heat discrete equations are given by:

$$
\left\{\begin{array}{c}
-A H_{j+1}^{i+1}+(1+2 A) H_{j}^{i+1}-A H_{j-1}^{i+1}=H_{j}^{i}-2 D T_{j}^{i}+D T_{j-1}^{i}+D T_{j+1}^{i} \\
B T_{j-1}^{i+1}+(2 B+1) T_{j}^{i+1}-B T_{j+1}^{i+1}=T_{j}^{i}-2 C H_{j}^{i}+C H_{j+1}^{i}+C H_{j-1}^{i}
\end{array}\right.
$$

With:

$\left.\boldsymbol{A}=\frac{\boldsymbol{D}_{H H} \Delta t}{(\Delta x)^{2}} ;{ }_{B}=\frac{\lambda+D_{T T}}{\rho_{s} C_{P}(\Delta x)^{2}}\right)^{2} ; C=\frac{D_{T H} \Delta t}{\rho_{S} C_{P}(\Delta x)^{2}} D=\frac{D_{H T} \Delta t}{(\Delta x)^{2}}$

$\mathrm{A}, \mathrm{B}, \mathrm{C}$ and $\mathrm{D}$ are given at the knots $(\mathrm{i}, \mathrm{j})$ with :

$x_{j}=x_{0}+j h, t_{i}=t_{0}+i l$

We have put the system (21.a) in the following matrix form:

$\left.\left.\left\lfloor E_{j}\right\rfloor G_{j}^{i+1}\right\rfloor+\left\lfloor F_{j}\right\rfloor G_{j-1}^{i+1}+G_{j+1}^{i+1}\right\rfloor=\left\lfloor H_{j}\right\rfloor$

With :

$\left[\boldsymbol{G}_{j}^{i}\right]=\left[\begin{array}{c}H_{j}^{i} \\ T_{j}^{i}\end{array}\right] \quad\left[E_{j}\right]=\left[\begin{array}{cc}2 A+1 & 0 \\ 0 & 2 B+1\end{array}\right] \quad, \quad\left[F_{j}\right]=\left[\begin{array}{cc}-A & 0 \\ 0 & -B\end{array}\right]$

$\left[H_{j}\right]=\left[\begin{array}{c}H_{j}^{i}+D T_{j-1}^{i}-2 D T_{j}^{i}+D T_{j+1}^{i} \\ T_{j}^{i}+C H_{j-1}^{i}-2 C H_{j}^{i}+C H_{j+1}^{i}\end{array}\right]$,

In order to have a recursive solution, we have considered that:

$\left[G_{j}^{i+1}\right]=\left[\gamma_{j}\right]-\left[\beta_{j}\right]^{-1}\left[F_{j} \llbracket\left[G_{j+1}^{i+1}\right]\right.$

With:

$\left[\gamma_{j}\right]=\frac{\left.\left\lfloor H_{j}\right\rfloor-\left\lfloor F_{j}\right\rfloor \gamma_{j-1}\right\rfloor}{\left[\beta_{j}\right]} ;\left[\beta_{j}\right]=\left[E_{j}\right]-\frac{\left\lfloor F_{j}\left\lfloor F_{j-1}\right\rfloor\right.}{\left[\beta_{j-1}\right]}$

Results can be progressively obtained. We have translated our program in the class 77 of fortran to generate all numerical results. Excel permitted us to draw our curves. The time step and space step are respectively $1700 \mathrm{~s}$ and $6.25 \times 10^{-4} \mathrm{~m}$. Initial temperature of samples is $28^{\circ} \mathrm{C}$. In each drying time $t_{i}$, from local values of humidity and the temperature of wood, average values are evaluated through relations 42 .a and 42.b.

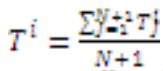

$$
\begin{aligned}
& H^{D}=\frac{\frac{N+1}{N+1} d i}{N+1}
\end{aligned}
$$

These are the values that will be represented on the following figures.

\section{Results and Discussion}

4.1. Experimental validation of the kinetic of drying applied on bete with constant air characteristics.

We are obtained experimental water content in each drying time respective then to validate the present modeling. We are used constant characteristics of air as the experiment. These characteristics are: Tair $=60^{\circ} \mathrm{C}$, , relative humidity of air equal to $30 \%$ and thickness of the plank is $25 \mathrm{~mm}$. according to figure 1, we note a same behavior between theoretical and experimental points. Here, we are determined in inverse mass transfer coefficient with heat transfer fixed at $11.2 \mathrm{~W} /\left(\mathrm{m}^{2} . \mathrm{K}\right)$ [1]. We are obtained $\mathrm{h}_{\mathrm{m}}=2,5 \times 10^{-7} \mathrm{~m} / \mathrm{s}$ and $\alpha=0.0045 \mathrm{~K}^{-1}$.

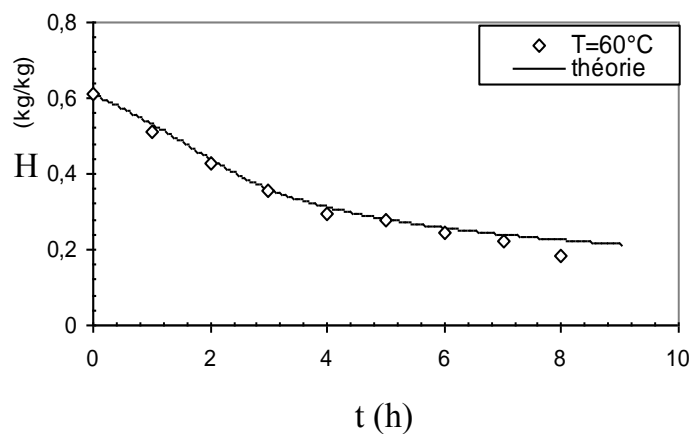

Fig.1: Drying kinetic of bete with constant conditions of drying air.

Thus, we can use a present modeling to study the behaviors of drying air and wood.

\subsection{Study of the sensibilities of our modeling during the drying of bete wood}

The plank of wood that we dried numerically have $1 \mathrm{~m}$ of length and the thickness will be precised each time. The drying is symmetric and the air circulates in the sense of the plank. All relationships on the paragraph 2 are utilized. The flow regime is laminar because Reynolds number is less than $3 * 10^{5}$. Drying table proposed by the Centre de Coopération International en Recherche Agronomique pour le Développement (CIRAD) [20] is utilized in the following. This drying table is illustrated in the table 1 for the thickness $\mathrm{e}<38 \mathrm{~mm}$ :

Table 1: Drying table of the bete wood [20]

\begin{tabular}{|c|c|c|c|}
\hline Humidity of & \multicolumn{2}{|c|}{ Temperature $\left({ }^{\circ} \mathrm{C}\right)$} & \multirow{2}{*}{$\begin{array}{c}\text { Relative } \\
\text { Humidity of } \\
\text { the air (\%) }\end{array}$} \\
\cline { 2 - 3 } & dry & Humid & 84 \\
\hline green & 50 & 47 & 75 \\
\hline 40 & 50 & 45 & 67 \\
\hline 30 & 55 & 47 & 47 \\
\hline 20 & 70 & 55 & 44 \\
\hline 15 & 75 & 58 & \multicolumn{2}{|c}{} \\
\hline
\end{tabular}

Figure 2 presents evolutions of the water content and the temperature of the wood in function of the drying time and the thickness of the plank. We note that drying time and thickness increase together when kinetic of the air and initial water content are constant. In effect, an explanation is the fact that when thickness increases, water in the wood is much confined. For to pass at the water content $60 \%$ to $20 \%$, thickness of the plank of wood is $15 \mathrm{~mm}, 20 \mathrm{~mm}$ or $25 \mathrm{~mm}$, the drying time required is respectively $31.5 \mathrm{~h}, 52.5 \mathrm{~h}$ and $79 \mathrm{~h}$, with the kinetic of the air is equal to $1.5 \mathrm{~m} / \mathrm{s}$ and the initial water content is $60 \%$. This same figure shows that when a thickness of the plank increases. In effect, the time of the repartition of the temperature in the thickness of plank become important, the energetic consummation is much important when the mass of wood to heat up increases. At the end of the drying, water content is not function of the thickness of the plank because water content at the equilibrium is not function of the temperature. 
Figure 3 shows that it is costly to dry the plank initially most humid because, more the wood is humid, less rapidly we attained the characteristics of the utilization of the plank. This same figure indicates that equilibrium water content is not function of the initial water content.

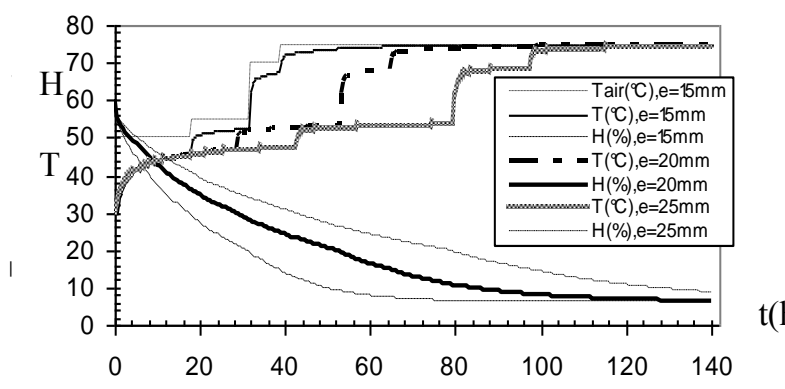

Fig.2: Drying kinetic in function of the thichness of wood at the conditions, $\mathrm{Va}=1.5 \mathrm{~m} / \mathrm{s}, \mathrm{K}_{\mathrm{L}}=5^{*} 10^{-18} \mathrm{~m}^{2}, \mathrm{H}_{0}=60 \%$

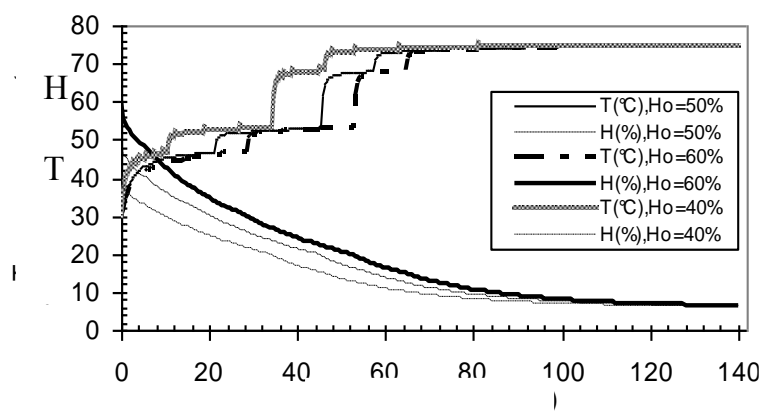

Fig.3: Influence of the initial water content on the drying kinetic of wood in the conditions: $\mathrm{e}=20 \mathrm{~mm}, \mathrm{Va}=1.5 \mathrm{~m} / \mathrm{s}, \mathrm{K}_{\mathrm{L}}=5 * 10^{-18} \mathrm{~m}^{2}$

Figure 4 shows that when the speed of the circulation of air increases, the speed of evolution of temperature of the wood increases equally, but the influence of this parameter is small at the level of evolution of water content. In this thickness, a drying is most influenced by interior migration of humidity. An important value of the speed of air causes a superficial drying of the plank than the interior layers. This surface can alternatively to dry and to absorb humidity and by consequently to destroy cellular tissues and the quality of the wood dried. High speeds can also to create turbulence and consequently it is possible to disturb the control of the characteristics of drying air through the plank.

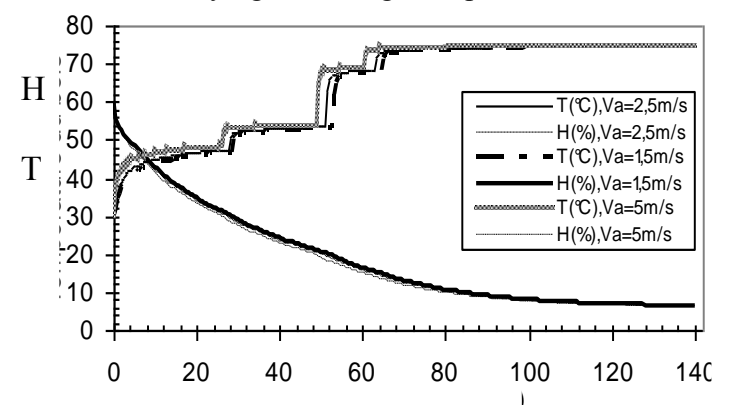

Fig.4: Influence of the speed of the circulation of air on the drying kinetic of bete in the conditions: $e=20 \mathrm{~mm}, \mathrm{~K}_{\mathrm{L}}=5 * 10^{-18} \mathrm{~m}^{2}, \mathrm{H}_{0}=60 \%$

Figure 5 presents the evolutions in the time of mass fraction of the vapor of water in air, of humidity of air and of humidity of air at the saturation state. With the time, air absorbs humidity given by wood. It is necessary, for to increase the drying kinetic (and to reduce the drying time), to evacuate the air of the dryer before his saturation. We note that the humidity of air in the dryer is nearly saturated after $55 \mathrm{~h}$ of the drying. In the following of the drying, the reduction of relative humidity of the air and the increasing of the dry temperature permitted to increase the power of evaporation of the air.

On the figures 2,3 and 4 , we can to observe the quickly variations of the temperature of the wood, of the air humidity and the mass fraction of the vapor in the air which are caused by abrupt changes of the characteristics of the drying air in order to respect the drying table.

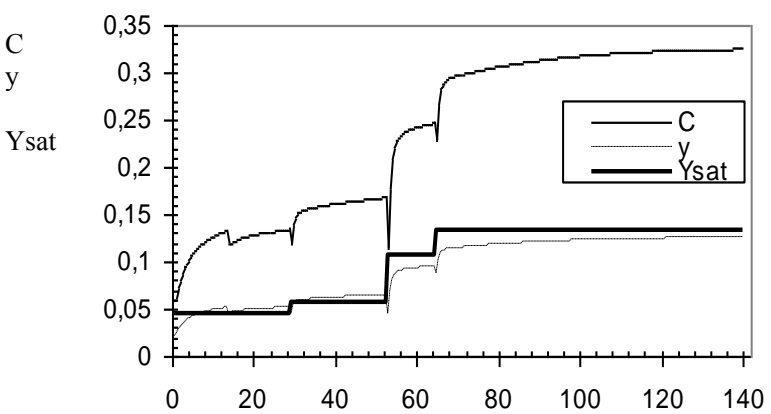

Fig.5: Evolution of the humidity of air in the time with $V_{\mathrm{a}}=1.5 \mathrm{~m} / \mathrm{s}$, $\mathrm{e}=20 \mathrm{~mm}, \mathrm{~K}_{\mathrm{L}}=5^{*} \mathbf{1 0}^{-18} \mathrm{~m}^{2}, \mathrm{H}_{0}=60 \%$

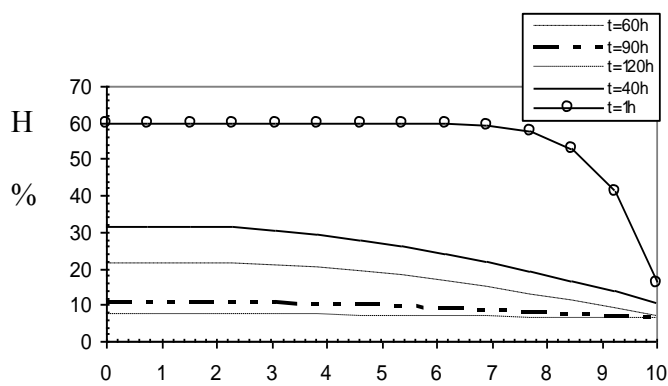

(a)

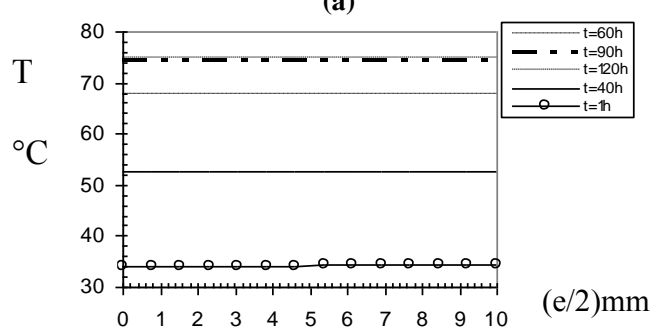

(b)

Fig.6: Variations of water content (a) et and the temperature (b) in the thickness of the plank in function of 5 times of the drying in the conditions: $H_{0}=60 \%, V_{a}=1.5 \mathrm{~m} / \mathrm{s}, \mathrm{e}=20 \mathrm{~mm}, \mathrm{~K}_{\mathrm{L}}=5 * 10^{-18} \mathrm{~m}^{2}$, drying table.

Figure 6 presents the evolutions of water content and the temperature in the thickness of the plank in four drying times. Immediately that the drying starts, water content on the surface of the plank decreases quickly and to bring nearer the value at the equilibrium. It is important to do careful in the following of the process because, an important re absorption of water or an important dry temperature can to destroy the surface of the plank. Figure 6a shows that it is difficult to extract the water in the center of the plank than in the surface region. Figure $6 \mathrm{~b}$ shows that the temperature to be uniform quickly in the thickness of wood, in consequently, soret effect is quickly reduces to zero. Desorption is then easy since this moment. 
Increase in the temperature of air permits to create the gradients of temperature in the plank and to generate the gradients of humidity which explain the movement of the water in the wood. It is important to control these gradients in other to reduce the barrier to the extraction of water and to favour an important not homogeneity of the humidity in the thickness of the plank. Important gradients can to create many failures as collapses and dimensions.

Figure 7 shows that during the drying of wood, the water content on the surface of wood is equal to the value at the equilibrium. We note that in general, we cannot to rich at the equilibrium point because water content of the utilization is important. Different abrupt modifications on the water content observed in the figure 7 are caused by the different modifications of the drying table. These modifications permit to reduce the equilibrium water content of water.

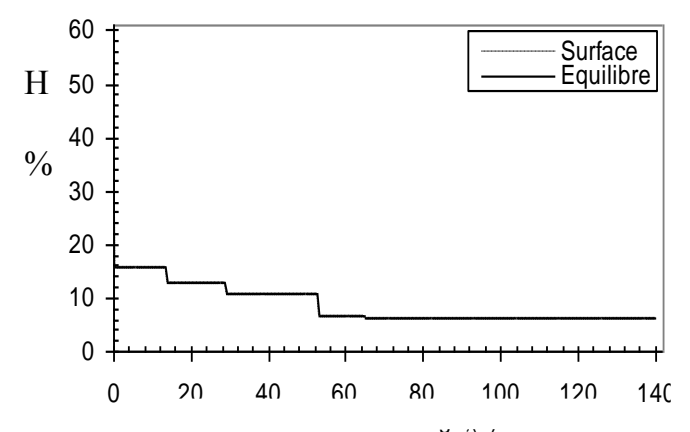

Fig.7: Variations of the water content at the surface and at the equilibrium with the drying time with the conditions: $\mathrm{H}_{0}=60 \%$, $\mathrm{V}_{\mathrm{a}}=1,5 \mathrm{~m} / \mathrm{s}, \mathrm{e}=20 \mathrm{~mm}, \mathrm{~K}_{\mathrm{L}}=5^{*} 10^{-18} \mathrm{~m}^{2}$, drying table.

It is most important to determine the own thermophysic characteristics of each wood studied because, a bad estimation can to generate a bad estimation of the energy required for to dry well our product. For example, we have evaluated the influence of liquid permeability on the wood. We observed that the variation of permeability shows a light variation of the kinetic (figures 8a and 8b). A good vision of the graph after $60 \mathrm{~h}$ of the drying shows that a bad estimation of the permeability can to change the value of final water content (figure $8 \mathrm{~b}$ ). In according to the literature, we note a small influence of the liquid permeability of the porous material on the drying kinetic [21].

\section{CONCLUSION}

For to dry biological material well good as bete wood, it is important to do the prevision on the requisite energy and the behavior of the material to dry when quality is necessary. Present modeling is a modest contribution to study the drying of tropical wood applied here on bete wood. Digital simulation obtained give general idea on evolutions with the drying time of the temperature, water content, humidity of air and the fraction of vapor in the drying air. All evolutions give a satisfaction behavior according to physic explanations. As example, a less influence of the permeability of the wood on the drying kinetic and absorption of humidity in the dryer by the drying air. This modeling can to be used to simulate the drying of biological materials at the high temperatures. As perspectives, for to ameliorate ours results, it is important to characterize experimentally the thermophysic parameters of the wood studied in function of temperature, thickness of material, relative humidity and the kinetic of drying air because many researchers said that thermophysic parameters varied with wood species and anatomical direction [22-34]. A great number of samples are necessary to generalize results.

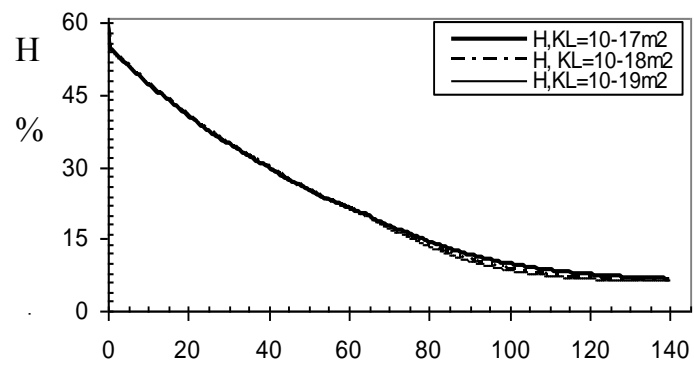

(a)

$\mathrm{t}(\mathrm{h})$

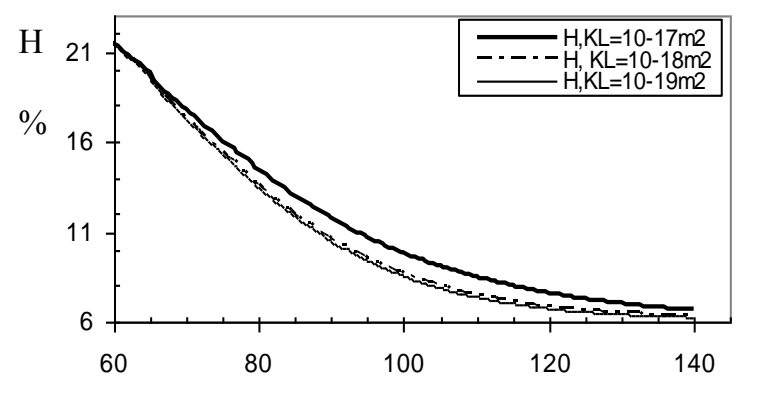

(b)

Fig. 8: Influence of the liquid permeability on the drying time in the condition: $e=20 \mathrm{~mm}, \mathrm{Va}=1.5 \mathrm{~m} / \mathrm{s}$

\section{Acknowledgments}

Author would like to thank Emeritus Professor André Zoulalian of the University of Lorraine (LERMAB) for all remarks and discussions then he gives in the preparation of this paper.

\section{References}

[1] M. Simo Tagne, B. Bonoma, D. Njomo .Modélisation et simulation numérique du séchage des bois d'ayous et d'ébène. Validation expérimentale. Revue des Energies Renouvelables. 2010; $13: \mathrm{N}^{\circ} 1: 13-24$

[2] W.T. Simpson, A. Ten Wolde. Physical properties and moisture relations of wood. Chapter 3, from Forest Products Laboratory, Wood Handbook, 463p .1999.

[3] D.F. Thies, V. Beligné. Note de synthèse économique du secteur forestier au Cameroun. GTZ et Coopération Française, 17 pages, 22/03/2007

[4] F. Verbelen. L'exploitation abusive des forêts équatoriales du Cameroun. Greenpeace Belgique, 49 pages, Octobre 1999

[5] T. Fomethe, Z. Tchanou. La gestion des écosystèmes forestiers du Cameroun à l'aube de l'an 2000.Vol.1,CEFDHAC-Processus de Brazzaville, IUCN, Yaoundé-Cameroun, 283pages, Décembre 1998.

[6] R. Jung (Revue par M. Debels) .Cameroun : la filière bois. Mission économique de Yaoundé, 6pages, Août 2003 
[7] A.Y.Koffi .Sciage artisanal, Transformation et sciage du bois d'œuvre du Cameroun à destination de l'arc soudanosaherien. Mémoire d'Ingénieur d'agronomie tropicale du CNEARC, Décembre 2005

[8] L. Remarche, A. Belhamri. Modélisation du séchage par convection. Revue des Energies Renouvelables. CISM'08, Oum El Bouaghi : 2008 ; 285-297

[9] H. Lumbroso. Problèmes résolus de thermodynamique. Physique de la matière. McGraw-Hill, $3^{\text {ième }}$ tirage, 1987.

[10] Merakeb Seddik. Modélisation des structures en bois en environnement variable.Thèse de Doctorat, Université de Limoges, 26 Septembre 2006.

[11] L. Monkam.Contribution à l'étude du séchage des bois tropicaux au Cameroun : Cas du Doussié, du Moabi et de 1'Iroko.Thèse de Doctorat, Université de Yaoundé I, 2006.

[12] J.P.Nadeau, J.R.Puiggali.Séchage, des processus physiques aux procédés industriels. Paris, New York, Londres, Tec and Doc, 307pages, 1995.

[13] R. Younsi, D. Kocaefe, S. Poncsak, Y. Kocaefe, L. Gastonguay.A high-temperature thermal treatment of wood using a multiscale computational model : Application to wood poles. Bioresource Technology. 9 pages; 2010; doi:10.1016/j.biortech.2010.01.089 (article in press)

[14] P.Horacek.Modelling of coupled moisture and heat transfer during wood drying. $8^{\text {th }}$ International IUFRO Wood Drying Conference .2003;372-378.

[15] J.M.Hernandez.Séchage du Chêne: Caractérisation, procédés convectif et sous vide. Thèse de Doctorat, Université de Bordeaux I .1991.

[16] Y.Jannot.Thermique Solaire .75pages ; Octobre 2003.

[17] M.Mourad, M.Hemati, C.Laguerie .Séchage intermittent de maïs en lit fluidisé à flottation : étude expérimentale et modélisation. Int. J. Heat Mass Transfer. 1997.vol.40, no5,1109-1119.

[18] D. Kocaefe, R. Younsi, S. Poncsak, Y. Kocaefe. Comparision of different models for the high-temperature heat-treatment of wood. Int. J. Thermal Sciences. 2007;46:707-716

[19] J. A. Mardini, A. S. Lavine, V. K. Dhir. Heat and mass transfer in wooden dowels during a simulated fire: an experimental and analytical study. Int. J. Heat Mass Transfer. Vol.39. 1996; No12; 2641-2651

[20] Tropix 6.0; Bété, CIRAD-Forêt, fiche $\mathrm{n}^{\circ} 187$ 2pages ,02/09/2008,

[21] G.E.Caceres Salazar;'’Modélisation du séchage d'un milieu poreux saturé déformable : prise en compte de la pression du liquide" Thèse de Doctorat de l'ENSAM, Centre de Bordeaux, 4 mai 2006
[22] B. Bonoma, M. Simo Tagne, L. Monkam. Influence of temperature and water content on the density and porosity of the tropical woods: Ayous, Baobab, Sapelli, Lotofa and Padouk. Physical and Chemical News. 2010; 51:79-83

[23] P.S. Ngohe-Ekam ;'Etude expérimentale des propriétés thermophysiques des bois tropicaux " Thèse de Doctorat, UCBL 1, 1992.

[24] H. E. Desch, J. M. Dinwoodie.Timber: Structure, properties. conversion and use" $7^{\text {th }}$ ed. Macmillan Press Ltd., London, 306p, 1996.

[25] Bond Brian, Hamner Peter. Wood identification for hardwood and softwood species native to Tennessee. Cours, Department de Forestrerie, University of Tennessee.

[26] W. T. Simpson. Physical properties and moisture relations of wood. Chapter 1 revised, from Forest Products Laboratory, Wood handbook, 463p, 1999.

[27] P. Chassagne, E. Vidal-Sallé, J.F. Jullien. Etude des phénomènes multi-physiques couplés : Application au bois sous les sollicitations thermo-hydro-mécaniques variables induites par l'opération de séchage. $7^{\text {ème }}$ colloque national en calcul des structures, Giens, 17-20 mai 2005

[28] B.Bonoma, M. Simo Tagne. Une contribution à l'étude du séchage de l'ayous et de l'ébène. Physical and Chemical News. $2005 ; 26: 52-56$

[29] D.S.Thomas, K.D.Montagu, J.P.Conroy .Changes in wood density of Eucalyptus camaldulensis due to temperatureThe physiological link between water viscosity and wood anatomy. Forest Ecology and Management. 2004 ;193:157-165 Doi:10.1016/j.foreco.2004.01.028

[30] A. Hai Alami.Mechanical and Thermal Properties of Solid Waste-Based Clay Composites Utilized as Insulating Materials. Int. J. of Thermal \& Environmental Engineering.Vol6(2):89-94DOI: 10.5383/ijtee.06.02.007

[31] J.L.Nsouandélé, B.Bonoma,M.Simo Tagne, D Njomo. Détermination du coefficient de diffusion de l'eau dans les bois tropicaux. Physical and Chemical News. 2010 ; $54: 61-67$

[32] S. Pang. Investigation of effects of wood variability and rheological properties on lumber drying: application of mathematical models. Chemical Engineering Journal. 2002;86: 103-110

[33] M.G. Pontin. Propriétés Physico-mécaniques de trois bois tropicaux au dessous et au dessus de la saturation des membranes. Mémoire de Maître en Sciences, Université de Laval, Québec, Avril 2005

[34] P.S. Ngohe-Ekam, P. Meukam, G. Menguy, P .Girard Thermophysical characterization of tropical wood used as building materials: with respect to the basal density. Construction and building materials. 2006; 20: 929-938. Doi: 10.1016/j.conbuildmat.2005.06.017 